\title{
Is end-stage renal disease always symptomatic?
}

\section{Son dönem böbrek hastalığı her zaman semptomatik midir?}

\author{
Rabia Alkan', Ebru Uz², Özlem Şahin Balçık², Burak Uz" ${ }^{4}$, Yeter Bayram ${ }^{1}$ \\ ${ }^{1}$ Fatih University School of Medicine, Department of Internal Medicine, Ankara, Turkey \\ ${ }^{2}$ Fatih University School of Medicine, Department of Nephrology, Ankara, Turkey \\ ${ }^{3}$ Fatih University School of Medicine, Department of Hematology, Ankara, Turkey \\ ${ }^{4}$ Hacettepe University School of Medicine, Department of Hematology, Ankara, Turkey \\ ${ }^{5}$ Fatih University School of Medicine, Department of Internal Medicine, Ankara, Turkey
}

\begin{abstract}
Chronic kidney disease presenting acutely is not uncommon, often avoidable and associated with adverse outcomes. In the early stages of chronic kidney disease, there may be no symptoms. However, when kidney function is less than one-tenth of normal, the symptoms may arise. The patients in end-stage renal disease may also present with nonspecific symptoms. A 46 year old man admitted to our hospital with knee pain. He had no other complaints. His blood urea and creatinin levels were 232 $\mathrm{mg} / \mathrm{dl}$ and $19.5 \mathrm{mg} / \mathrm{dl}$ respectively. He was anemic and venous blood gas revealed $\mathrm{pH}: 7.10, \mathrm{HCO}_{3}: 10 \mathrm{mEq} / \mathrm{L}$. But his physical examination was normal. The glomerular filtration rate was greatly reduced, altough his blood pressure was within normal limits. Hemodialysis had been initiated immediately and within 24 hours blood urea nitrogen had decreased to $145 \mathrm{mg} / \mathrm{dl}$. The clinicians must be aware of non-spesific symptoms such as arthralgia, which should masquerade the underlying chronic kidney disease. The identification, follow-up and appropriate referral of patients with raised serum creatinine is likely to reduce its incidence. J Clin Exp Invest 2010; 1(3): 216-218
\end{abstract}

Key words: chronic kidney disease, glomerular filtration rate, hemodialysis, kidney function tests, acidosis

\section{INTRODUCTION}

Chronic kidney disease (CKD) is characterized with progressive loss of renal functions over a period of months or years. In recent years, it has been identifed as a major health concern worldwide due to its high prevalence, high cost and its effect on life quality. CKD can be diagnosed by simple blood and

\section{ÖZET}

Kronik böbrek hastalığının akut olarak ortaya çıkması nadir değildir. Bu durumdan sıklıkla kaçınılabilir, fakat gelişmesi halinde olumsuz sonuçlar doğurabilir. Kronik böbrek hastalığı erken dönemlerde asemptomatik seyredebilir. Böbrek fonksiyonları normal düzeyinin onda birinin altına düştüğünde semptomlar ortaya çıkabilir. Fakat, son dönem böbrek yetmezliği hastaları non-spesifik semptomlarla da başvurabilirler. Hastanemize başvuran 46 yaşındaki erkek hastanın diz ağrısı dışında şikayeti yoktu. Üre ve kreatinin değerleri sırasıyla $232 \mathrm{mg} / \mathrm{dl}$ ve $19.5 \mathrm{mg} / \mathrm{dl}$ idi. Anemisi mevcuttu. Venöz kan gazı değerlendirmesinde $\mathrm{pH}: 7.10, \mathrm{HCO}_{3}^{-:}: 10 \mathrm{mEq} / \mathrm{L}$ idi. Fakat hastanın fizik muayenesi normaldi. Hesaplanan glomerüler filtrasyon hızı oldukça düşük olarak bulunmasına karşın kan basıncı normal sınırlar içerisindeydi. Acil olarak hemodiyalize alınan hastanın kan üre nitrojeni 24 saat içerisinde 145 mg/ dl'ye geriledi. Klinisyenler kronik böbrek hastalığını maskeleyebilecek artralji gibi non-spesifik semptomlara karşı uyanık olmalılardır. Bu durumun insidansının azaltılabilmesi, yüksek serum kreatinini olan hastaların tanınması, takibi ve uygun olarak sevk edilmeleri ile sağlanabilir. Klin Den Ar Derg 2010; 1(3): 216-218

Anahtar kelimeler: Kronik böbrek hastalığı, glomerüler filtrasyon hızı, hemodiyaliz, böbrek fonksiyon testleri, asidoz

urine tests, as recommended in guidelines issued by the National Kidney Foundation. CKD was categorized according to the decrease in glomerular filtration rate (GFR) (Table 1) ${ }^{1}$.

CKD slowly gets worse over time. In the early stages, there may be no symptoms. The loss of function usually takes months or years to occur. But 
when kidney function is less than one-tenth of normal, the symptoms occur. The aim of this report is to emphasize that the patients may be asymptomatic despite of metabolic asidosis and high plasma concentrations of creatinine and urea in end-stage renal disease.

Table1. Classification of chronic kidney disease according to the US National Foundation's staging system, the Kidney Disease Outcomes Quality İnitiative

\begin{tabular}{lll}
\hline Stage & Definition & GFR $\left(\mathrm{mL} / \mathrm{dk} / 1.73 \mathrm{~m}^{2}\right)$ \\
\hline Stage 1 & Kidney damage with normal or raised GFR & $>90 \mathrm{~mL} / \mathrm{min} / 1.73 \mathrm{~m}^{2}$ \\
Stage 2 & Mild reduction in GFR & $60-89 \mathrm{~mL} / \mathrm{min} / 1.73 \mathrm{~m}^{2}$ \\
Stage 3 & Moderate reduction in GFR & $30-59 \mathrm{~mL} / \mathrm{min} / 1.73 \mathrm{~m}^{2}$ \\
Stage 4 & Severe reduction in GFR & $15-29 \mathrm{~mL} / \mathrm{min} / 1.73 \mathrm{~m}^{2}$ \\
Stage 5 & Kidney failure, end-stage renal disease & GFR $<15 \mathrm{~mL} / \mathrm{min} / 1.73 \mathrm{~m}^{2}$ or dialysis \\
\hline
\end{tabular}

\section{CASE REPORT}

A 46 year old man applied to our hospital with knee pain. He had no other complaints. Fifteen days ago, non-steroidal antiinflammatory drug and myorelaxant treatments were given to the patient in a village clinic, but his complaints did not improve. In his medical history there was not any chronic disease and renal function abnormality. The blood pressure was $120 / 80 \mathrm{mmHg}$ and the apical heart beat was 88/min. Physical examination was normal. Laboratory findings were: the blood urea nitrogen 232 $\mathrm{mg} / \mathrm{dl}$, creatinine $19.5 \mathrm{mg} / \mathrm{dl}, \mathrm{Na} 134 \mathrm{mmol} / \mathrm{L}, \mathrm{K}$ $4.8 \mathrm{mmol} / \mathrm{L}, \mathrm{Hb} 6 \mathrm{gr} / \mathrm{dl}$, Htc 17\%, white cell count $5200 / \mathrm{mm}^{3}$, platelets $238.000 / \mathrm{mm}^{3}$, Ca $4.7 \mathrm{mg} / \mathrm{dl}, \mathrm{P}$ $11.9 \mathrm{mmol} / \mathrm{L}$, albumin $4.1 \mathrm{gr} / \mathrm{dl}$, intact PTH $702 \mathrm{pg} /$ $\mathrm{ml}$. The anemia parameters were as follows; ferritin $176 \mathrm{ng} / \mathrm{ml}$, iron $67 \mathrm{ug} / \mathrm{dL}$, iron binding capacity 166 $\mathrm{ug} / \mathrm{dl}$, transferrin saturation $28.6 \%$, B12 $741 \mathrm{pg} / \mathrm{ml}$, folic acid $7.4 \mathrm{ng} / \mathrm{ml}$. The venous blood gas results were appropriate for metabolic asidosis $(\mathrm{pH}$ : 7.10, $\left.\mathrm{HCO}_{3}^{-:} 10 \mathrm{mEq} / \mathrm{L}, \mathrm{PCO}_{2}: 27 \mathrm{mmHg}, \mathrm{BE}: 17\right)$. Our patient's glomerular filtration rate was calculated as $3 \mathrm{ml} / \mathrm{min} / 1.73 \mathrm{~m} 2$ according to MDRD formula. He was oliguric and 2,7 gr/24 hours proteinuria was detected in urinalysis test. Chest x-ray was normal. Urinary ultrasonography revealed a renal appearance consistent with chronic renal disease (bilateral renal sizes were decreased with increased parenchymal echogenicity of grade III)

Hemodialysis had been initiated immediately and within 24 hours blood urea nitrogen had decreased to $145 \mathrm{mg} / \mathrm{dl}$. Antiphosphate and erythro- poietin treatments were initiated. The patient is on follow-up in hemodialysis program. Etiology of chronic renal failure is unknown for now.

\section{DISCUSSION}

Chronic kidney disease is a long-standing process with progressive deterioration of the renal functions. Several different body systems may be affected in case of renal insufficiency. Symptoms develop slowly and include anorexia, nausea, vomiting, stomatitis, nocturia, fatigue, pruritus, decreased mental activity, muscle twitches and cramps, water retention, undernutrition, gastrointestinal ulceration and bleeding, and peripheral neuropathies ${ }^{1,2}$. This patient presented with only a non-spesific symptom, knee pain. Laboratory results revealed abnormality in renal functions, metabolic acidosis, and ultrasonographic findings were compatible with CKD. Therefore, he underwent hemodialysis programme.

Plasma concentrations of creatinine and urea (which are highly dependent on glomerular filtration) begin a nonlinear rise as GFR diminishes. But when the GFR falls below $10 \mathrm{ml} / \mathrm{min} / 1.73 \mathrm{~m} 2$, their levels increase rapidly and are usually associated with systemic manifestations (uremia). Urea and creatinine are not major contributors to the uremic symptoms; there are many other substances (some of them not yet well defined) that cause the symptoms.

With more severe renal insufficiency (creatinine clearance $<10 \mathrm{~mL} / \mathrm{min}$ ), usually in consequence of 
hypertensive or metabolic encephalopathy, neuromuscular symptoms may be present including coarse muscular twitches, peripheral sensory and motor neuropathies, muscle cramps and hyperreflexia. Pruritus, anorexia, nausea, vomiting, weight loss, stomatitis, and an unpleasant taste in the mouth are almost uniformly present. Lassitude, fatigue, anorexia, and decreased mental activity often are the earliest manifestations of uremia. In our case, GFR was $3 \mathrm{ml} / \mathrm{min} / 1.73 \mathrm{~m} 2$ but he did not have any mentioned uremic symptoms.

Metabolic acidosis, due to accumulation of sulfates, phosphates, uric acid etc. often is mixed, has a normal and/or increased anion gap ${ }^{2}$. In chronic kidney disease, the kidneys are unable to produce enough ammonia in the proximal tubules to excrete the endogenous acid into the urine in the form of ammonium. Metabolic asidosis is associated with protein-energy malnutrition, loss of body mass, muscle weakness and bone disease. Although he had a metabolic acidosis, there were not any of these findings. The ability to maintain potassium excretion at near normal levels is generally induced by both aldosterone secretion and distal flow function. Another defense mechanism against potassium retention in patients with chronic kidney disease is increased potassium excretion in the gastrointestinal tract. Therefore, hyperkalemia usually develops when the GFR falls to less than $20-25 \mathrm{~mL} / \mathrm{min}$ because of the decreased ability of the kidneys to excrete potassium. In our case, blood potassium level was normal despite of severe reduction in GFR.

Salt and water balance is altered in patients with chronic kidney disease. This generally becomes clinically manifested when the GFR falls to less than $10-15 \mathrm{~mL} / \mathrm{min}$, when compensatory mechanisms have become exhausted. Sodium retention and extracellular volume expansion cause to peripheral and pulmonary edema and hypertension. High blood pressure is almost always present during all stages of chronic kidney disease. Hypertension is present in $>80 \%$ of patients with $\mathrm{CKD}$, is usually related to hypervolemia, and is occasionally the result of activation of the renin-angiotensin-aldosterone system. In this patient, the blood sodium level was normal and his blood pressure was $120 / 80 \mathrm{mmHg}$. However, chronic renal disease may sometimes present with non-specific symptoms. Review of 202 consecutive patients with irreversible chronic kidney disease showed that 15 (7\%) had required dialysis immediately or within 7 days of presentation. Analysis of their records showed eight avoidable late referrals who had not had their renal function checked. Gastrointestinal symptoms were common and led to further delays in diagnosis, with three patients having endoscopy requested before their bloods were checked. Physical and psychological morbidity associated with this form of presentation was high $^{3}$. The identification, follow-up and appropriate referral of patients with raised serum creatinine is likely to reduce acute presentation of CKD incidence.

In conclusion, the patients in stage 5 chronic renal failure may present with nonspecific symptoms. Screening the basal creatinin value is very important for early diagnosis of renal failure in the patients who have nonspecific symptoms like only joint pain and/or dyspepsia.

\section{REFERENCES}

1. Crowe E, Halpin D, Stevens P. Early identification and management of chronic kidney disease: summary of NICE guidance. BMJ 2008;337:812-6.

2. Adrogué HJ, Madias NE. Changes in plasma potassium concentration during acute acid-base disturbances. Am J Med 1981;71:456-67.

3. Wolfe M, Almond A, Robertson S, Donaldson K, Isles C. Chronic kidney disease presenting acutely: presentation, clinical features and outcome of patients with irreversible chronic kidney disease who require dialysis immediately. Postgrad Med J 2010;86:405-8. 